\title{
Ethical Leadership and Business Decision Making in Contemporary Times
}

\author{
Aristarchus A A Nikoi \\ Aristarchus Nikoi 49 Day Street, Norwalk CT 06854 \\ E-mail: a.anikoi@yahoo.com
}

\begin{abstract}
Leadership in recent times has seen increasing corporate scandals resulting in the collapse of hitherto reputable organizations, such as Enron and WorldCom. The canker of unethical leadership cuts across international boundaries, culture and societies. From business and sociological stand points, the consequences of unethical leadership behavior are insurmountable. The general objective of this paper is to look at leadership ethics and how it influences leadership decisions making and the exercise of good judgment.

It was observed that the main role of leadership is setting new direction and getting people along this direction. However, resent leadership scandals have made people see leaders with some kind of skepticism. Laws and legislations are good, but their existence has not deterred unscrupulous leaders for example in the Enron case. Dealing with this issue in a pragmatic way is critical to minimizing this situation if not eradicating it. Although situations may differ from one problem to the other, a careful review of previews decision provides some guidance in dealing with similar issues. It is my sincere believe that the model developed in this study would help develop the needed understanding of leadership ethic s and judgment, and how to deal with the current situation in our society.
\end{abstract}

Keywords: Ethical Leadership Business Decision Making

\section{Introduction}

Leadership in recent times has seen increasing corporate scandals resulting in the collapse of hitherto reputable organizations, such as Enron and WorldCom. The business environment may be likened to: "In those days Israel has no king; everyone did as he saw fit" (Judges 21:25). The lack of ethical behavior of our leaders led to the promulgation and signing of the Corporate Corruption Bill into law by the President of the United States on July 30, 2002, and the subsequent approval of H.R. 1257 by the House of Representatives. The issue of leadership ethics goes beyond mere promulgation of laws. What, then, is leadership ethics? What are the effects of unethical leadership behavior? Are there any remedies to unethical leadership behavior?

This treatise will take a general view of leadership ethics and how it influences leadership decision making in all facets of life. A more critical look will be made at philosophies of ethics and how it has influenced people's way of life and judgment. Also this paper will look at current thinking on leadership ethics. The study will also identify some of unethical leadership behaviors, and suggest remedies.

\subsection{Objectives of the paper}

The general objective of this paper is to look at leadership ethics and how it influences leadership decisions making and the exercise of good judgment. This paper will specifically:

(1) Discuss leadership ethics and some of the concerns in the current business environment;

(2) Discuss some of the unethical leadership behaviors; and

(3) Identify the effects of unethical leadership behaviors on communities and propose remedies.

\section{Literature review and conceptual framework}

In his book, "Business Ethics," Velasquez (2006) wrote that "ethics is the discipline that examines one's moral standards or the moral standard of a society (p.10)". (p. 2)". Velasquez et al (1988) in an attempt to bring clarity to the meaning of ethics observed that ethics is not 1) the same as feelings; 2) religion; 3) following the law; 4) following culturally accepted norms or 5) science where important data could be used to make ethical choices. Christensen and Kohls (2003) observed that an ethical decision is one that the decision maker makes a decision which accords all stakeholders the needed intrinsic value. 
Plato, Socrates and Aristotle and other great philosophers all sought to identify and imbued in their followers the best ethical way of life. As Hadot (2002) noted that Plato pushed his agenda of the ethical way of life through the establishment of "an intellectual and spiritual community whose job is to train new human beings (p.59). His program of training and research in the Academy had primarily an ethical perspective with the objective of purifying the mind and getting students to live in a typical philosophical way (p.65). Aristotle, according to Hadot in the same fashion founded the Lyceum, and the objective here was not so different from Plato's idea of ethically purifying and developing the mind of his students. Aristotle, like Plato, held the view that the establishment of a school was the best way to develop a community in which the ideal life could be lived to its fullest.

This ancient idea of developing a community that imbued in its students the best ethical way of life still permeates our educational institutions. In Ghana, formal education was first introduced by missionaries whose education and training was built on the foundation of strict Christian principles. To date, churches like the Presbyterian, Methodist, Catholic, and the Ahamadya Muslim Mission have control over their schools. As someone who went through the Presbyterian school system, I experienced strong emphasis on scripture as the bedrock of my training. In the United State, where diversity is highly tolerated, it is evident that institutions such as Regent and Eastern Universities emphasize the development of Christian leadership as their main objective in education.

In an attempt to live this best way of life, we usually get caught up with the issue of battling the two major forces that always live with us; good or bad; for or against, in all facets of our human endeavors. Fromm (1997) in his book "to have or to be" explained that these two major forces struggle in the spirit of humankind dictateing what goes on in our thoughts and actions. Fromm observed that overemphasis on the "having" mode which concentrates on material things has given rise to greed in the world, and believes that the "being" mode seeks to develop in us an ethical way of life.

Bass and Steidlmeier (1998) observed that "ethics of leadership rests upon three pillars: 1) the moral character of the leader, 2) the ethical values embedded in the leader's vision, articulation, and program which followers either embrace or reject, and 3) the morality of the processes of social ethical choice and action that the leaders and followers engage in and collectively pursue. This could be presented diagrammatically as shown in figl below.

Figure 1.

From the above diagram it can be seen that ethical leadership is dictated by the interaction of moral character and ethical values inherent in leadership vision; and, how the society perceive and processes morality and ethics. It may therefore not be arguable that leadership ethics refers to the standard of behavior that tells us the expected actions and inactions of leaders.

Thinking about standards, I wonder which standards are reasonable, and whether they may apply in all situations. So long as the issue of situations and societal influence play critical roles in setting standards, it would be right to say that an issue which may be perceived as unethical in the United States may be ethical in Ghana for example. This holds true only on issues that are strongly influenced by culture and the law. For instance homosexuality is a lawful practice in the Netherlands; the US does not have any law regulating this practice, and in Ghana it is illegal. Additionally, bribery, nepotism, sexual and gender discrimination in any form is highly unacceptable in the United States, but in other parts of the globe such as Africa, Latin America, and the Arab states it is not a big deal. Although laws and regulations are usually propounded to influence moral behavior, the exercise of good judgment is usually left with the leadership.

Rest's (1986) model of ethical interpersonal communication is a good source for making good leadership judgment. This model takes a linear approach, and it ensures that in moral decision making leaders take one step at a time. It has four stages altogether as shown in the diagram below.

Figure 2. Rest's (1986 Model of Ethical Interpersonal Communication

The model seeks to guide leaders in their decision making process. It helps leaders analyze their actions and inactions and also understand how these actions and inactions impact stakeholders both negatively and positively. The first stage is moral sensitivity, it is the first stage of the decision making process, and it is at this stage that the quality of the judgment is carved. At the moral judgment stage, the actual selection of the leader's action takes place in when consideration the impact an action would have on stakeholders. The moral motivation depicts the inspiration from which the decision is made, and finally the moral action is implemented.

It could be said from the above that leadership ethics rests solidly on the moral character and conduct of the leader and what s/he seeks to achieve. Kotter (1990) corroborated this by noting that leadership is about coping with change; developing a vision of the future along with strategies for producing the changes needed; aligning people to the vision by communicating clearly the new direction; motivating and inspiring people to move toward thie new direction, despite major obstacles; also, by appealing to basic but often untapped human needs, values, and emotions (P. 104).

\section{Ethical leadership issues}

The canker of unethical leadership cuts across international boundaries, culture and societies. It must be pointed out that the problem of poverty in developing countries to a greater extent is caused by lack of ethical leadership. Sub-Saharan 
Africa has seen and continues to see political and economic instability. In Ghana, for instance, I saw the country experiencing a high degree of military adventurism in the 70 s and early $80 \mathrm{~s}$. All these governments cited corruption and lack of equitable distribution of economic resources as the main reason for their intervention. In 1979 alone, the country saw one civilian and two military administrations.

In January 2001, a new democratic administration was sworn into office, and in his inaugural speech, president Kuffour declared zero tolerance for corruption. Both Ghanaians and the international community gave a sigh of relief and developed some confidence in this new government. It was not long before this same president in response to allegations about the corruptions in his government said that even Adam was corrupt and that corruption is as old as Adam. This perhaps was to prepare the mind of the public for what he had in store, as he himself was involved in various improprieties ranging from infidelity to illegal amassing of property. He further challenged those who accuse his government of corrupting to come out with facts when a survey by Integrity International indicated that the public has no confidence in the government.

In other countries such as Cote de Ivore, Liberia, Sierra Leon, Democratic Republic of Congo, and the current unrest in Kenya explains the extent to which immoral and unethical behavior could lead us. The genocide in Rwanda and the then apartheid system in South Africa explain the negative role unethical leader can play.

In the US, various scandals have befallen many public officials, and we seemed to be in an era where corruption by leaders has become the order of the day as there are unethical leaders in almost every profession, industry, and business. There is no single day that the dust of leadership scandal intends to settle. If it is not dubious business deals, then it is the compromise of leadership position for personal gains or sexual misconduct. Some of these unethical behaviors that come to mind are: the Clinton-Lewinsky 1998 scandal, his lying under oath, and subsequent impeachment; Gov. McGreevy's sex scandal and Gov. Spitzer's involvement in a prostitution ring. Gov. Spitzer is quoted to have said that he "acted in a way that violates his obligation to his family......."I apologize first and most importantly to my family. I apologize to the public, to whom I promised better..."I am disappointed that I failed to live up to the standard I expected of myself"

The Abramoff scandal led to the resignation of Senate Majority Leader Tom Delay after he was rebuked by a bipartisan House ethics panel for improprieties. Lewis "Scooter" Libby, Dick Cheney's former Chief of Staff was indicted by a grand jury on five counts of felony for making false statements to federal investigators. He was tried and convicted, but his sentence was later commuted by President Bush.

The private sector is no exception, as the Enron case quickly rings a bell whenever the issue of unethical leadership is raised. Ken Lay, an economist and former undersecretary at the US Department Interior, formed Enron in 1985 by influencing the merger of two companies that dealt in gas. This merger made Enron the largest natural gas company capable of supplying gas to the whole country. Enron was called the seventh largest company in the April 2001 issue of Fortune magazine. The unethical decision by the company's leadership to "cook the books" coupled with their lack of openness to the workers and shareholder led to the eventual fall of the great company.

Other unethical leadership behavior include Wal-Mart the world's largest retail organization in regards to its continues abuse of employees and discrimination; the Bhopal incident that killed thousands of Indians; the demise of Andersen, one of the world's largest consulting firms; the Watergate scandal that the led to the resignation of president Nixon and Martha Steward's incarceration are some of the high profiles of unethical leadership that have been seen in the history of the United States. Cornehis (2004), aptly puts it "What was originally proclaimed to be one or two rogue corporations and their executives enriching themselves and their friends now has become a flood of reported ill-gotten gains and financial irregularities" (p. 29) For more information on unethical practices see the appendix A.

\subsection{The negative impact of unethical leadership}

The consequences of unethical leadership could be looked at from various perspectives, but in this paper let me limit it to business and social perspectives. From the business stand point, the consequences of unethical leadership behavior are insurmountable. The Enron case for instance led to the total collapse of a company that was then adjudged by Fortune magazine as the seventh-largest in the United States, and the most innovative company in America. A company that was seen as the best place for investment, and commanded the trust of institutional investors and individuals alike ended up shattering the dreams of these investors. Not only did the fortune of these investors go down the drain, but also the trust of the business public. It could be argued that this is not the first time people have lost their investment and that any kind of investment comes with a risk. It is however clear that most investors and businesses see risk as unforeseeable business environmental occurrences and not one that comes from corrupt and unethical leaders.

The issue of untrustworthiness that comes with the Enron case is the same with all forms of business, be they public or private. For example the Ghanaian public lost confidence in the Kuffour administration when he back tracked his earlier stance and proclamation of zero tolerance for corruption. The Abramoff scandal, Tom Delay's impropriety, and the conduct of the Bush administration in relation to the Iraq war, led to the rejection of the Republican Party in the November 2006 Congressional Elections. 
On the social front unethical leadership behavior causes strife, psychological torture and crime. Taking the Enron case in perspective, it is clear that not only did twelve thousand people lose their jobs, but also their entire retirement and life savings which had been invested in Enron stocks. In the case of WorldCom seventeen thousand employees lost their jobs, and Arthur Andersen's involvement in both the Enron and WorldCom cases did not only lead to the demise of the company but also the livelihood of its employees. The fall of these three major companies, was not by mere default, but due to highly unethical behavior of its leaders. In the Enron and WorldCom cases twenty-nine families were affected and factoring the collapse of Andersen the number of families that lost income is highly incredible.

The financial cost of unethical behavior to customers is highly disturbing. For instance, in order to correct the "cooked books" WorldCom's MCI increased its rates from 5 cents to 9 cents a minute. Not only did this increase the expenditure of consumers, but also the tax payer. Yes, the tax payer because at that time the Pentagon was one of MCI's largest customers.

Regarding the impact of scandals such as Clinton-Lewinsky, Gov. McGreevy, and Gov. Spitzer, it does not only erode the public trust of leadership, but the precedence set by these ends up reshaping the societal culture of what is right or wrong. In the wake of Gov. Spitzer's scandal, some commentators made references to the Clinton-Lewinsky scandal and suggested that if Clinton who lied under oath survived his presidency then it is possible that Gov. Spitzer would survive his governorship. Although Gov. Spitzer resigned few days after the issue became public, it is dangerous to use one bad scandal such as the Clinton-Lewinsky scandal as a yardstick for measuring other scandals. It would be nothing more than a continuous lowering of our moral standards.

\subsection{How do we reverse this trend?}

I postulated here that if ethical leadership is not following the law, religion or the cultural dictates of the society as suggested by Velasquez al (1988), it would be difficult to deny the influence of morality; character; the vision of the leader, and judgment. Morality is the ability to identify what is generally accepted by the society as right or wrong. It is allowing our conscience to influence our action and inaction towards objects with which we interact. In order to make ethical decisions, I argue that leaders must: 1) understand and identify the vision/mission of the issue at stake; 2) analyze the ethical sensitivity imbedded in the issue or situation; 3) analyze the various decisions from an ethical perspective; 4) examine the inherent motivation for the needed ethical decision; 5) make a decision that has the best ethical impact on the stakeholders; and finally 6) review the decision made. This is what I call the ethical leadership decision making process model as shown below. It is my fervent belief that if this model is carefully applied it would minimize the existing canker of unethical leadership.

Figure 3. Ethical Leadership Decision Making Process Model

The above model suggests that in order to make good and ethical leadership judgments this process must be followed. Let us look at each of these stages in context and how critical they are to making ethical judgments.

\subsubsection{Leadership vision}

It is common knowledge that no one makes a trip without knowing where s/he is going or expects to be, why the trip should be made, and how to get there. It is only when a leader clearly understands his or her vision, and aligns it to the situation, event or the object at stake that $\mathrm{s} / \mathrm{he}$ is able to make good and ethical judgments. Analysis of the vision also includes acknowledging the all stakeholders inherent in the vision or the new direction being sought. Gov. Spitzer, for instance, promised good and ethical governance, and President Kuffour assured the Ghanaian public both during his campaign and inaugural speech of zero tolerance of corruption. However, their actions suggest that they lost sight of what they had stood for and sought.

\subsubsection{Embedded ethical sensitivity}

This stage takes into consideration the nature and the ethical sensitivity surrounding the situation, event or the object involved. This usually involves the "how" of achieving the leader's vision which may present various scenarios. At this stage, it is important to understand the issue from the different perspectives that may be held by the various stakeholders associated with the issue. Evan and Freeman (1998) noted that stakeholders do not prefer to be used merely for organizational ends, but have the right to participate in any decision that affects them (p. 103). In business for instance, leaders are required not only to satisfy customers, but also the shareholders and employees. In the Enron case, it appears that the company's desire to impress its shareholders, did not only lead to the fraudulent misrepresentation of the financial statements, but also disregarded the interest of its employees.

\subsubsection{Ethical decision analysis}

Analyzing the sensitivity reposed in the issue gives the leader the needed background to examine the various options available to responding to the issue at stake. Had Enron been sensitive to all the stakeholders, it would have made a decision that benefited all of them. One unethical decision eventually leads to others. Enron's decision to go into other ventures such as paper pulp, aluminum, steel, lumber and plastics did not only deviated from the company's original 
vision but also made worse the company's financial woes. The critical question that must be answered during this stage of the process are; 1) How does this decision help achieve the company's vision? 2) Does this decision address the sensitivity of all stakeholders? This assertion is supported by Bowie's (1998) suggestion that in making any rules, moral savvy organizations should; 1) consider the interests of all affected stakeholders in any decision made; 2) get input from all the affected stakeholders; 3) the interests of one stakeholder should not take priority over the other; 4) establish procedures to insure that relations among stakeholders are governed by rules of justice (p.47).

\subsubsection{Ethical motivation}

The ethical motivation stage seeks to analyze the driving force behind the desire of leadership to make a particular decision. Such a decision must be devoured of any emotion, and strong emotional intelligence here is very critical. Is it the morality surrounding the decision? Is it the pressure from special interests? Is it the sense of achievement? Wherever this inspiration is coming from, it should be one that would at the end of the day satisfy all the stakeholders. In the Enron and WorldCom cases, it is clear that the selfishness of the leaders overshadowed the interest of employees, customers, and the shareholders. It is also undeniable that these various sex scandals that have befallen leaders like Gov. Spitzer was motivated by self interest.

\subsubsection{Review the decision made}

In all aspects of my life I had always identified from hindsight certain decision that I would never had made, and I believe most people would feel the same. It is very important that leaders conduct an After Action Review (AAR) especially on any decision that posed a lot of challenges. It is true that situations may vary, but a thorough AAR would equip leaders with the knowledge to approach similar situations whenever one arrives. Gavetti and Rivking (2005) supported this when they suggested that strategists' success in thinking is by 'tapping the power of analogy'.

\section{Conclusion}

The main role of leadership is setting new direction and getting people along this direction. However, resent leadership scandals have made people see leaders with some kind of skepticism. Laws and legislations are good, but their existence has not deterred unscrupulous leaders for example in the Enron case. Dealing with this issue in a pragmatic way is critical to minimizing this situation if not eradicating it. Although situations may differ from one problem to the other, a careful review of previews decision provides some guidance in dealing with similar issues. It is my sincere believe that the model developed in this study would help develop the needed understanding of leadership ethic $\mathrm{s}$ and judgment, and how to deal with the current situation in our society.

\section{References}

Bass, Bernard M. and Steidlmeier, P (1998). Ethics, Character, and Authentic Transformational Leadership, Center for Leadership Studies, Binghamton University, Binghamton, NY

Bowie, N. (1998). A Kantian theory of capitalism. Business Ethics Quarterly, (special issue 1), 37-60.

Cornehis, J. V. (2004) Veblen's theory of finance capitalism and contemporary corporate America. Journal of Economic issue, 38(1), 29-58

Evan, W. M., and Freeman, R. A. (1988). A stakeholder theory of the modern corporation: Kantian capitalism. In T. Donaldson and P. H. Werhane (Eds.), Ethical issues in business ( $3^{\text {rd }}$ ed., p. 97-106). Upper Saddle River, NJ: prentice Hall.

Fromm, Erich (1997). To Have or To Be? Continuum, New York

Hadot, Pierre, (2002). What is Ancient Philosophy? Harvard University Press

http://politicalticker.blogs.cnn.com/

http://www.forbes.com/2002/07/25/accountingtracker.html

Patsuris, P. (2002). The corporate scandal sheet. Forbes.com, Work/Management. Retrieved March $15^{\text {th }} 2008$, from http://www.forbes.com/2002/07/25/accountingtracker.html

Rest, J. R. (1986). Moral Development: Advances in research and theory. New York:Praeger

The Holy Bible. (2002). Zondervan New International Version Study Bible, Grand Rapids, Michigan (p.482)

Velesquez, Manuel E. et al. (1998). A Framework for Thinking Ethically, Issues Ethics, Vol. 1, No. 2 (Winter 1998).

Velesquez, Manuel E. (2006). Business Ethics, Concepts and Cases. Pearson Education Inc. Upper Saddle River, NJ 


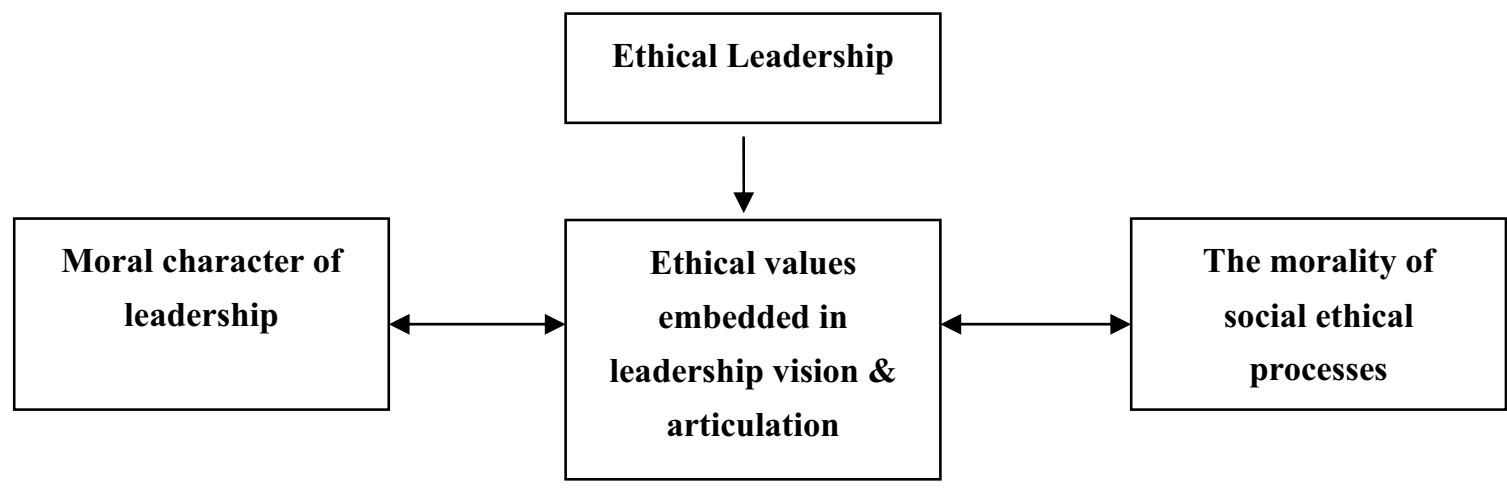

Figure 1.

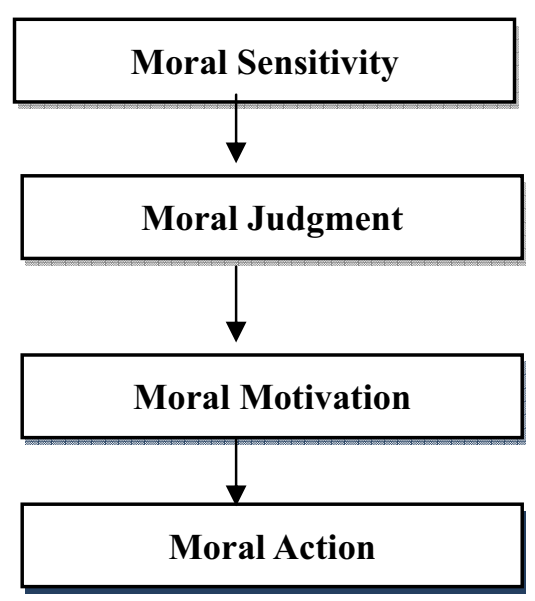

Figure 2.

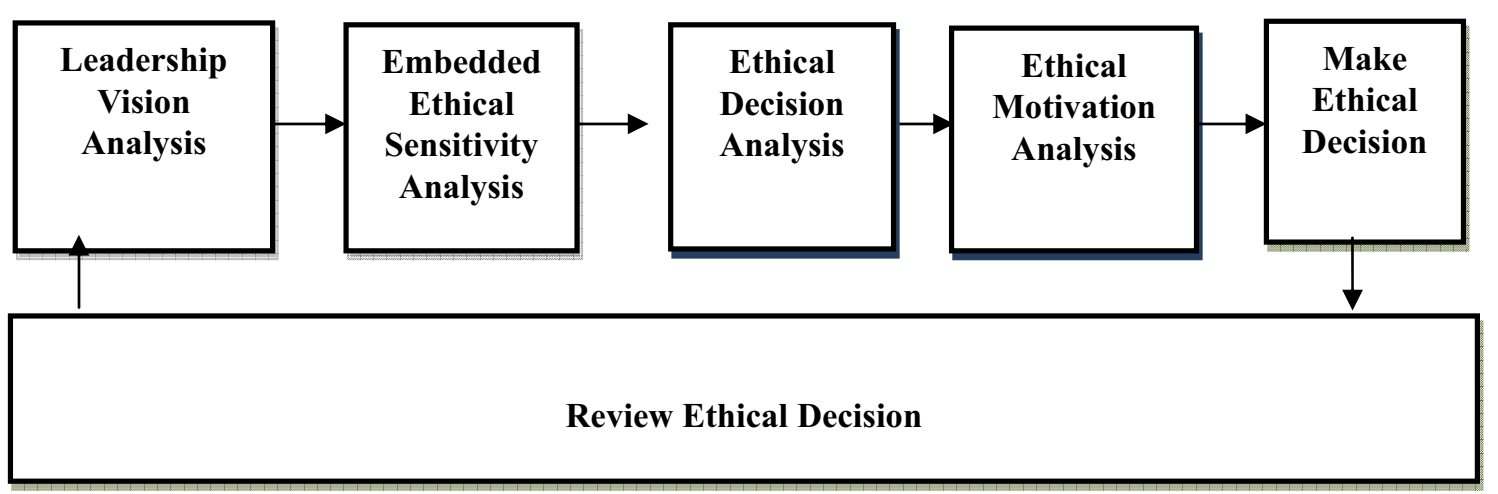

Figure 3. Ethical Leadership Decision Making Process Model 


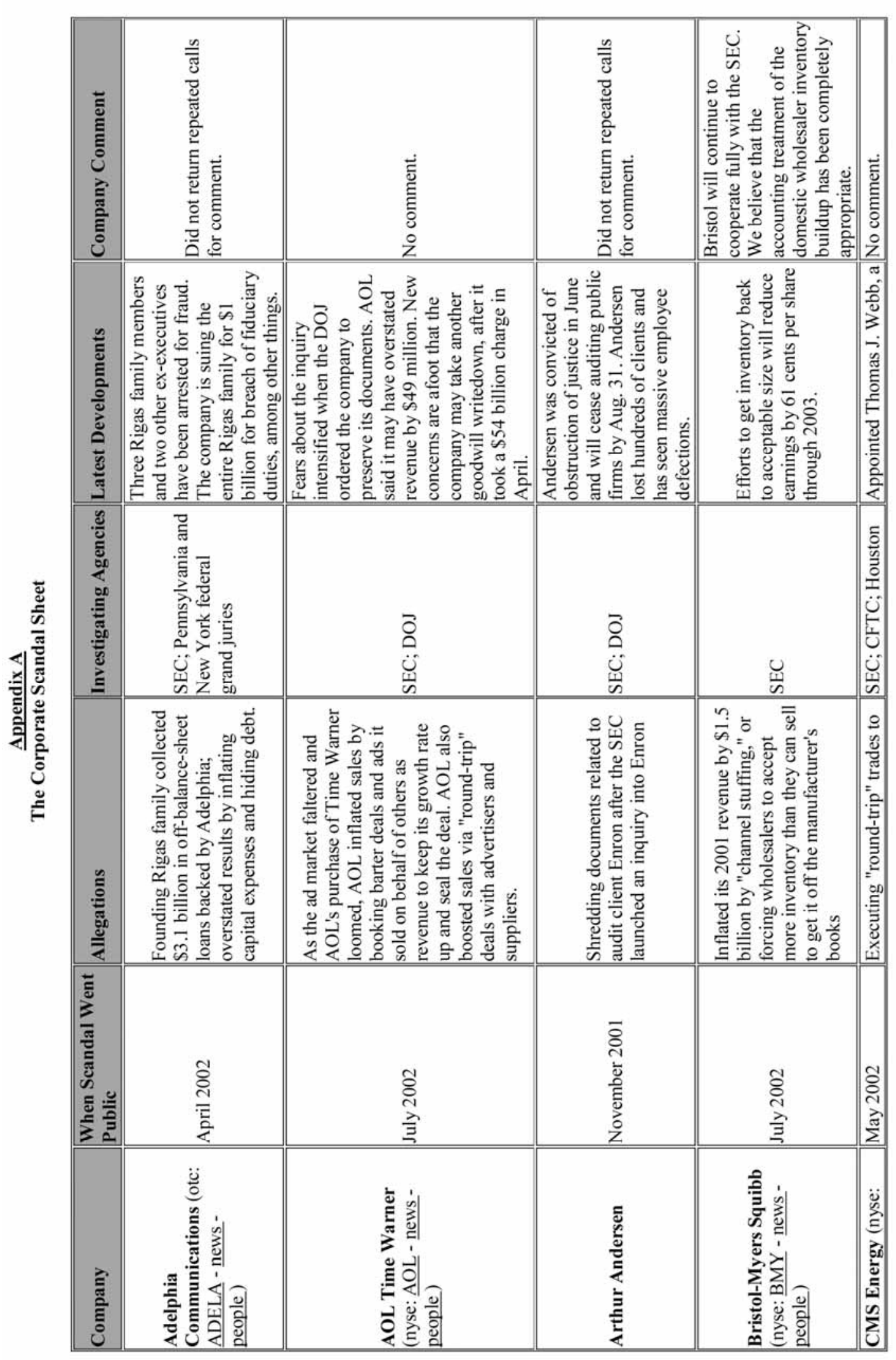




\begin{tabular}{|c|c|c|c|c|}
\hline & 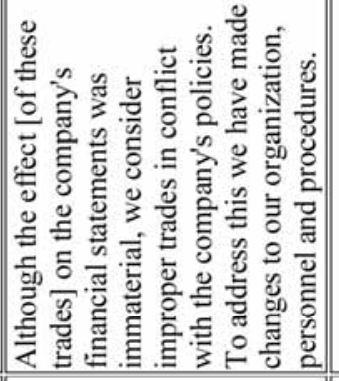 & 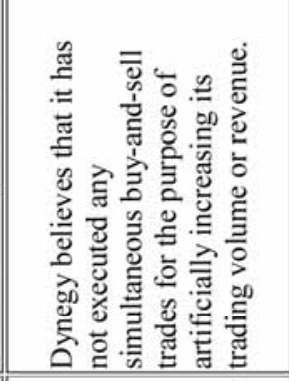 & 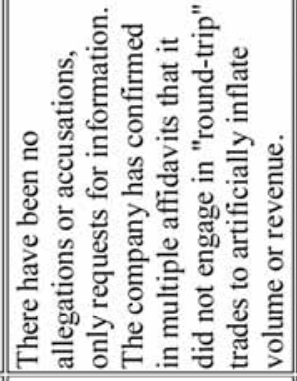 & 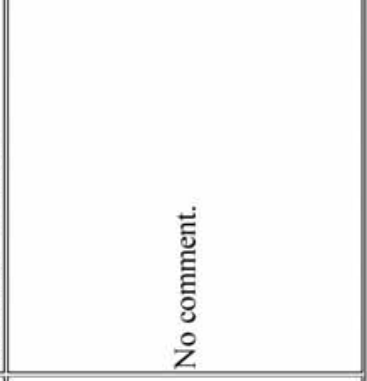 \\
\hline 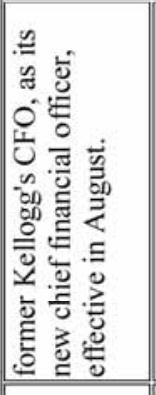 & 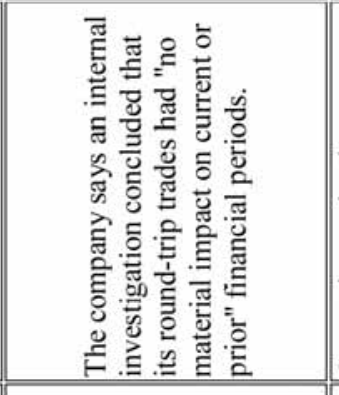 & 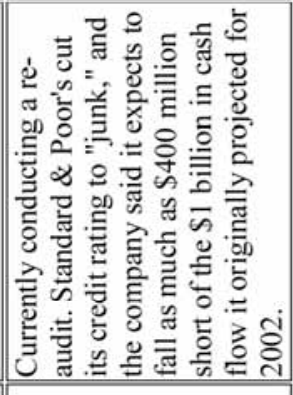 & 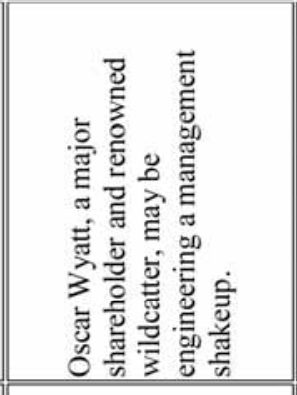 & 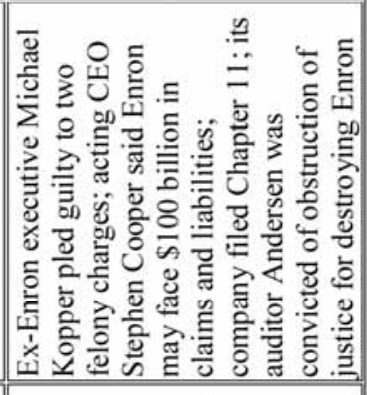 \\
\hline 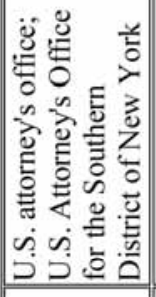 & 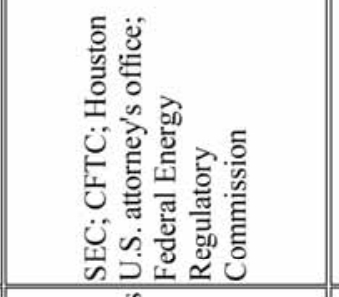 & 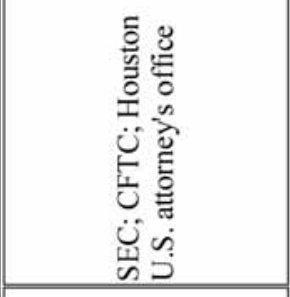 & 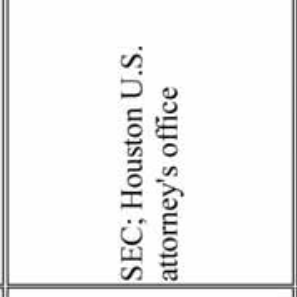 & 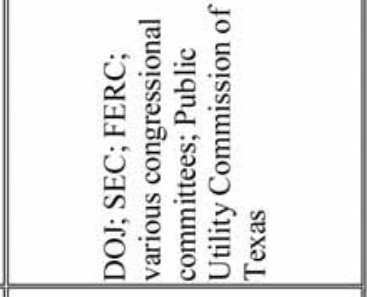 \\
\hline 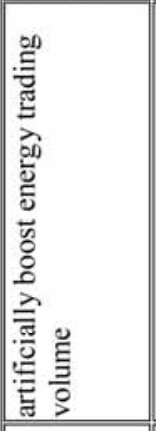 & 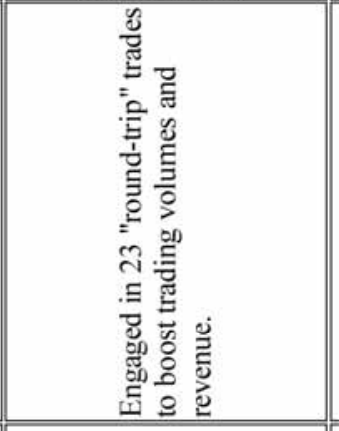 & 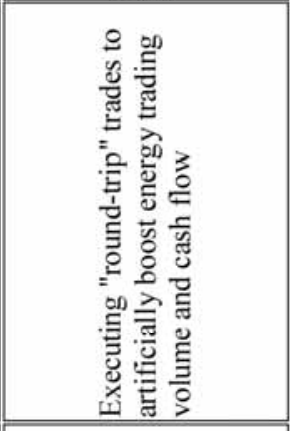 & 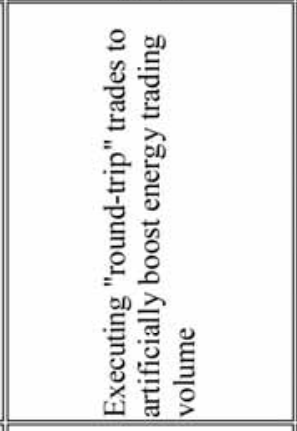 & 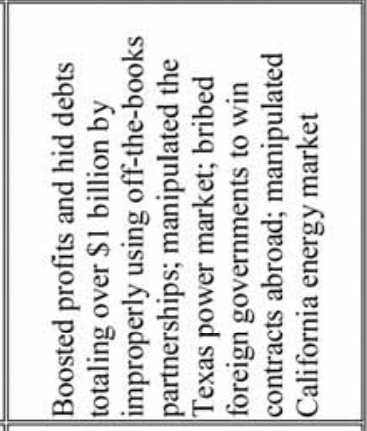 \\
\hline & 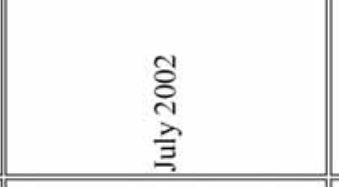 & 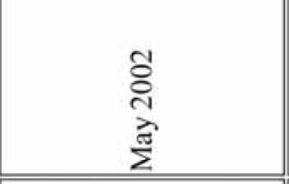 & $\begin{array}{l}\text { ¿े } \\
\text { ते } \\
\text { త্ } \\
\Sigma\end{array}$ & 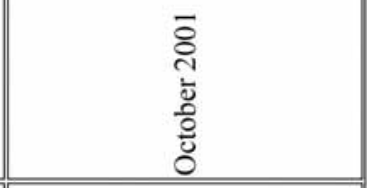 \\
\hline 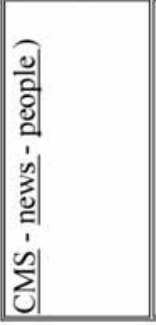 & 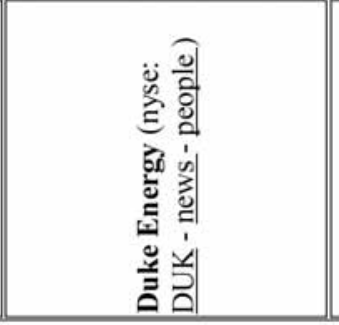 & 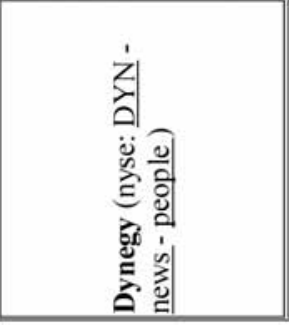 & 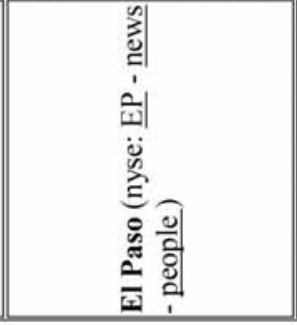 & 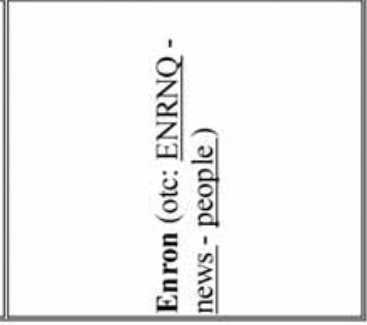 \\
\hline
\end{tabular}




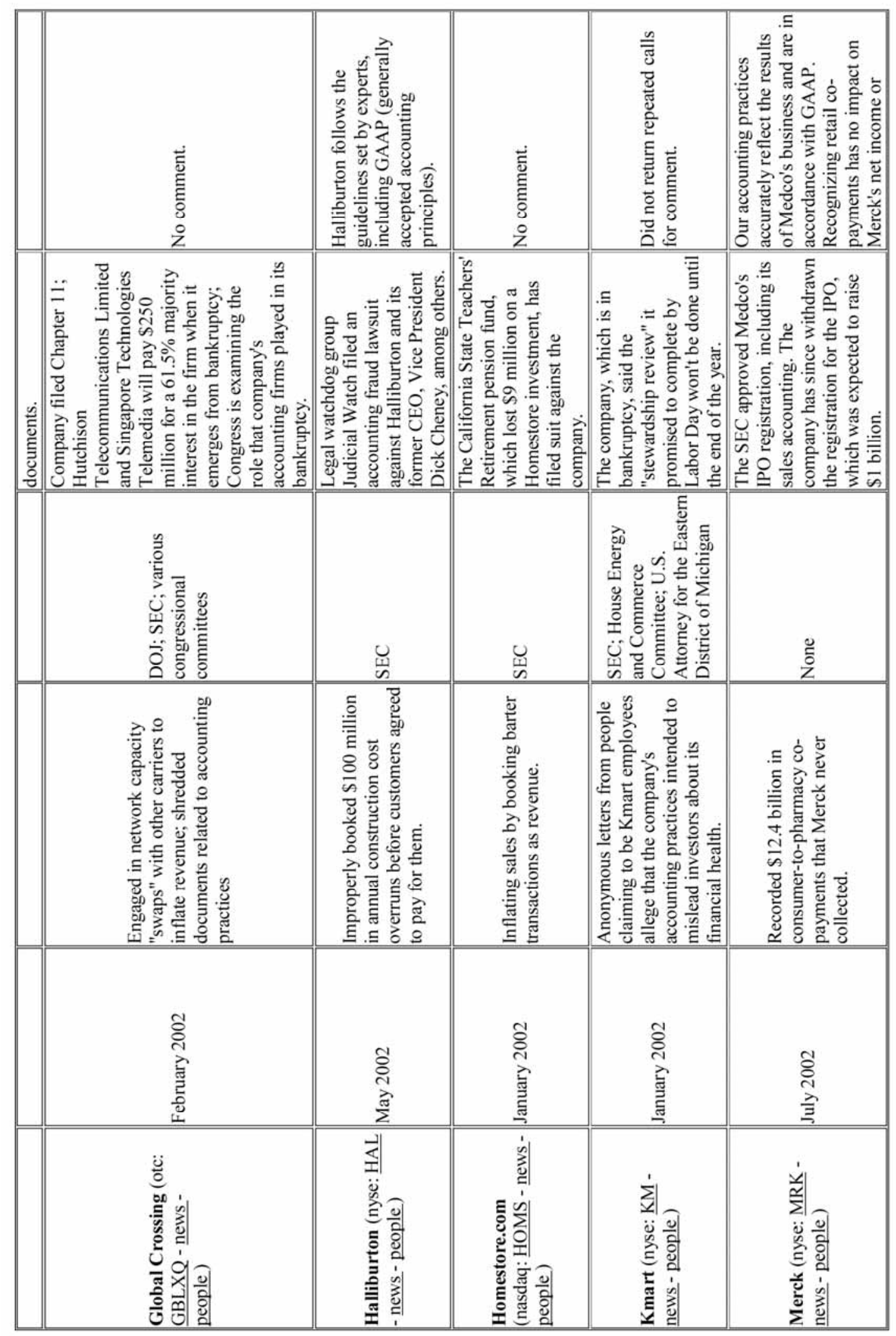




\begin{tabular}{|c|c|c|c|c|c|c|}
\hline & 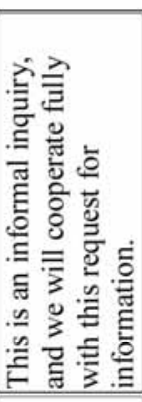 & 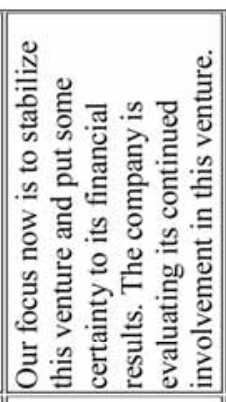 & 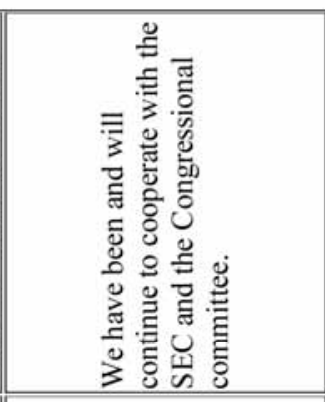 & 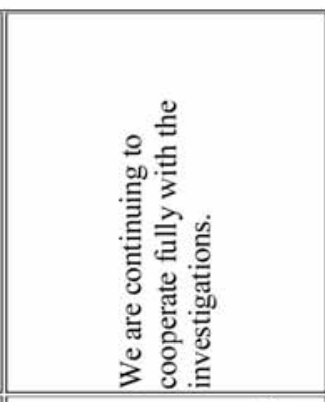 & 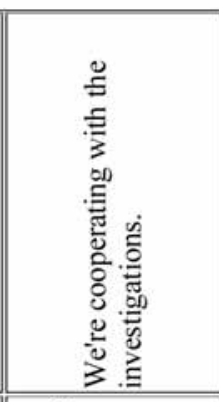 & 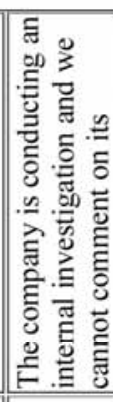 \\
\hline & 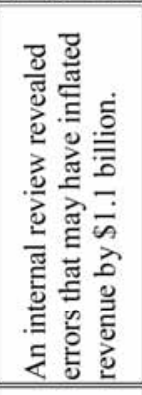 & 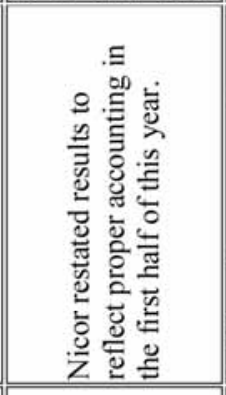 & 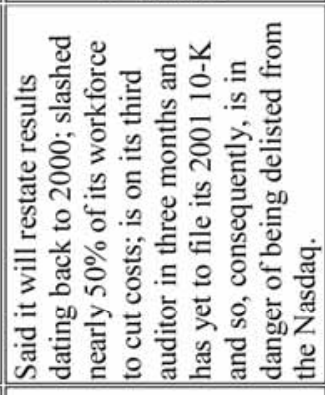 & 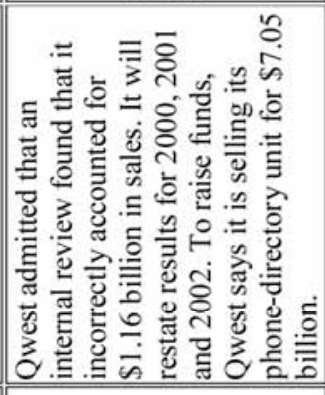 & 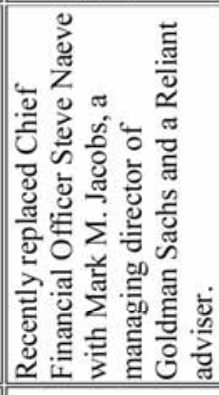 & 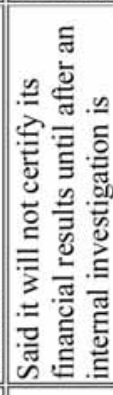 \\
\hline & 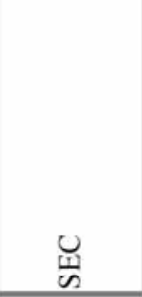 & ह̆ & 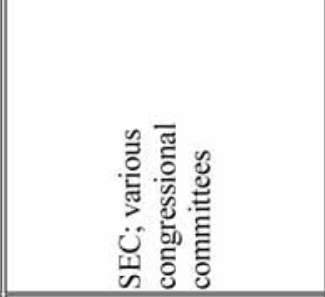 & 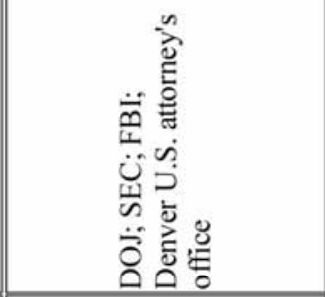 & 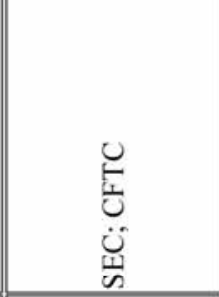 & 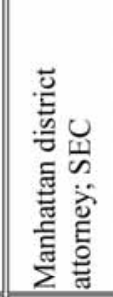 \\
\hline & 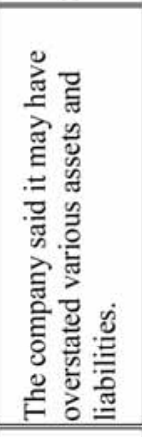 & 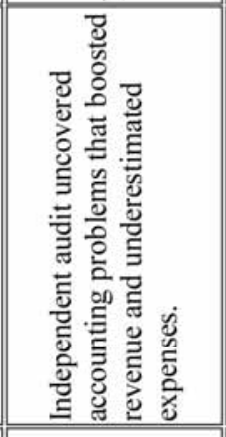 & 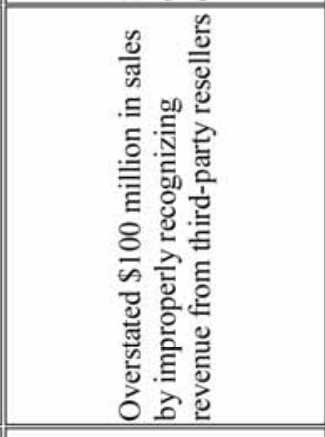 & 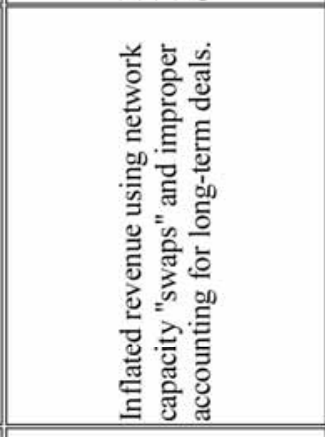 & 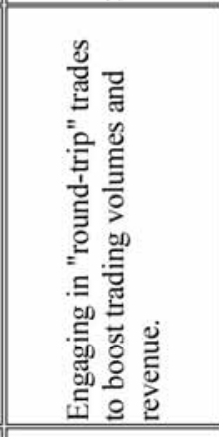 & 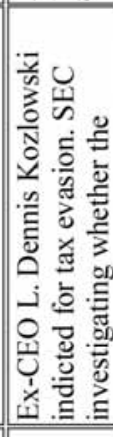 \\
\hline & 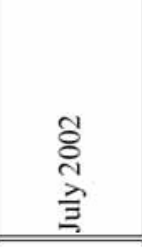 & 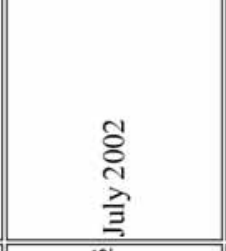 & ֻั & 芯 & ठิ & 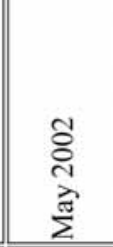 \\
\hline & 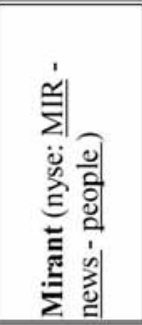 & 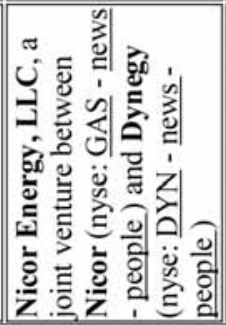 & 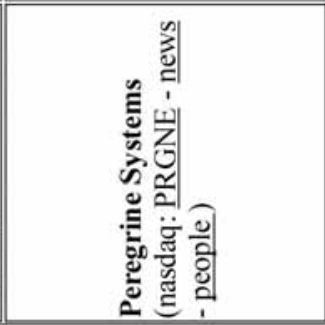 & 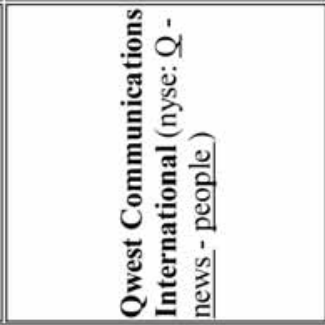 & 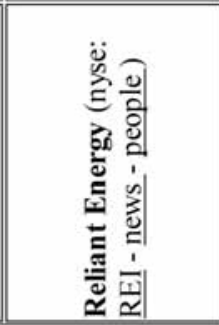 & 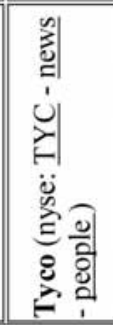 \\
\hline
\end{tabular}




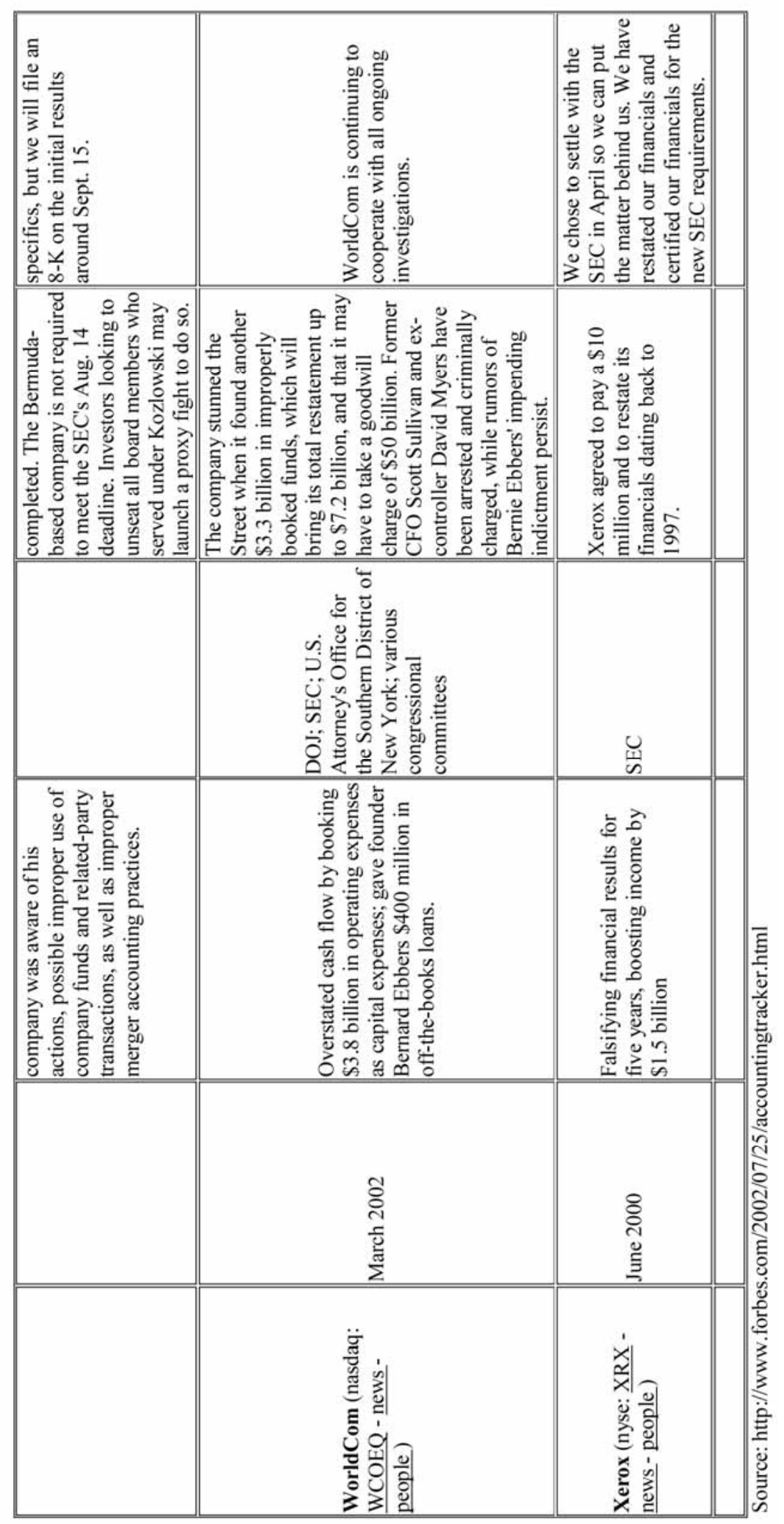

